\title{
Ryan Patrick Hanley (ed.), Adam Smith. His Life, Thought and Legacy, Princeton Univeristy Press, Princeton-0xford 2016, pp. 571
}

Adam Smith: His Life, Thought and Legacy edited by Ryan Patrick Hanley is a collection of essays devoted to Adam Smith's philosophy and economy, reaching out to the wider context, as well as including remarks concerning modern approach to Smith's legacy. Essays collected in the Adam Smith... refer to numerous aspects of Adam Smith's philosophy. Each of the chapters has been written by a different author who has managed to include his or her own approach to the subject. As usually, such a composition of the book has its advantages and disadvantages: contributions of numerous respected scholars on the one hand allow to become familiarized with different approaches towards one author and getting to know different points of view, whereas, on the other hand, they result in a partial inconsistency of the book.

The book has been divided into five sections that cover different aspects of Smith's thought and each of them seems to play its part in the book treated as a whole. The first section is composed of seven chapters devoted to Smith's biography, his Lectures on Rhetoric and Belles Lettres, The Theory of Moral Sentiments, the Lectures on Jurisprudence, Essays on Philosophical Subjects and the best known of Smith's works: the Wealth of Nations. The last chapter of this section aims to present Smith as Scottish philosopher, a member of the Scottish Enlightenment, providing a wider perspective. All these essays provide a very brief

1 Institute of Philosophy, Faculty of Humanities, Nicolaus Copernicus University in Toruń, Poland, markwart.anna@gmail.com. The research was financed from the assets awarded by The National Science Centre, Poland, for the post-doctoral internship upon the decision no. 2016/20/S/ HS1/00071. 
account of the subjects they are to discuss, mentioning some basic facts, trying to sum up the state of knowledge and include authors' interpretations.

The form of short pieces written by individual authors does not provide them with the possibility to fully describe the ideas that can be found in the discussed Smith's works and express their own approach to the subject. However, the chapters included in the first part of Adam Smith... are in fact a brief summary of the aspects of philosophy covered by Smith, mentioning the current state of knowledge, covering not only the best known Smith's works, but also his lectures and remarks on other - not that frequently analyzed - subjects. For instance Craig Smith's chapter devoted to Essays on Philosophical Subjects provides an interesting account of chosen aspects covered by Adam Smith's Essays. His summary of the philosopher's theory of science can be regarded as a valuable insight on that subject.

Unfortunately, it can be seen that such short chapters are not enough to fully present neither the mentioned works of the Scottish philosopher nor the modern discussions. An experienced Smith scholar might find most of these chapters too superficial, whereas someone for whom it is one of the first contacts with Smith's philosophy would consider them too incoherent and assuming too much previous knowledge.

However, it needs to be mentioned that the editor himself admits that the scholars who contributed for the book have not aimed to duplicate the contents of other interesting works on Adam Smith (Hanley, 2016, p. X), such as The Cambridge Companion to Adam Smith (Haakonssen, 2006) or The Oxford Handbook of Adam Smith (Berry, Paganelli, Smith, 2013). It can be easily seen that the authors have a very deepened knowledge of the subjects they discuss and had to make very hard choices, trying to prepare such short summaries of Smith's works. Yet, it needs to be underlined that presenting the books, essays, and accounts of lectures presented by Smith can serve as a guide when looking for more specific information, presenting the wide variety of issues undertaken by the author of the Wealth of Nations. All of the chapters devoted to Smith's particular works or lectures were written by top Smith scholars. Among the essays especially noteworthy is the one written by Vivienne Brown, dedicated to the Lectures on Rhetoric and Belles Lettres. She commences her essay by stating that "The sociality of human life is fundamental for Adam Smith's writings. Human beings are social beings; an inquiry into ways of life, history, or morals must start from an understanding of this sociality rather than from any notion of an individual abstracted from social context” (Hanley, 2016, p. 17). This way Brown manages not only to point out the most interesting issues discussed in the lectures, but also presents them in context of Smith's philosophy, mentioning her own opinions about the philosopher's achievements. 
Vivienne Brown focuses on Smith's views concerning rhetorics, underlining his originality and correspondence with his thought as a whole and using it's ideas to analyze Smith's books: stating that “The Theory of Moral Sentiments and the Wealth of Nations deal with different subject matter, but the rhetorical theory of LRBL suggests that they have it in common that they are both complex rhetorical works” (Hanley, 2016, p. 29).

The second section of the book is devoted to "Smith's Social Vision", gathering essays devoted to self-interest, virtues, justice, imagination, equality, and freedom. The authors aim to present these concepts, treating them as essential to understanding Smith's thought and extrapolate further ideas of Smith's views on these subjects. This section, though refers to the presence of sociability in Smith's thought and touches issues out of which some were widely discussed in the literature of the subject, also includes ideas that weren’t fully described by Adam Smith and presents an unorthodox approach towards his thought. I find this part of the book one of the most interesting ones. Fresh ideas are merged with deepened information, placed in a wide context of Smith's philosophy.

The chapter written by Ryan Patrick Hanley entitled Adam Smith on Living a Life commences from a couple of remarks concerning human nature and the world we live in. Further on it presents an interesting hypothesis stating that "Both Smith's life and work are in fact animated to a striking degree by a concern to respond precisely to the challenge outlined by Rousseau: namely to describe a way of life that might enable us today to recover some semblance of unity and also to render ourselves good and useful both to others and to ourselves” (Hanley, 2016, p. 124). However, as he notices himself: "This is, of course, not how Smith's project is often seen” (Hanley, 2016, p. 124). Hanley notes that Smith regards a human being as a social being, who is divided between caring for oneself and concern for others which results in situations when one of these paths needs to be chosen. The author also states that, in Smith's theory, some advice on how to live a life can be found - he underlines the role of self-approbation and praiseworthiness, underlining that trying to develop ourselves is a way to live in harmony with others. Hanley mentions notions of self-perfection and sociability that seem to be quite characteristic for Smith's philosophy and sheds a new light on them, proving how much is still to be done and how many issues can be still discovered in relation to Adam Smith's thought.

The third section of Adam Smith... aims at presenting Smith's economic views, focusing, however, on his significance for modern economic theory. It is to be noted that the authors of the essays included in this part of the book do not aim to provide a summary of Smith's economic thought. They have all rather decided to 
pick several ideas of his and show that these are still valid for understanding of economic theory and can be extended to theories that have been developed long after Smith. I find this approach very constructive and efficient: there have been numerous works devoted to Smith's economy and it would have been impossible to summarize the Wealth of Nations having so little pages to be filled. Even the famous "invisible hand" has been devoted only a few brief paragraphs - yet the reader interested in the subject can find interesting discussions of this issue elsewhere, including the essay by Gavin Kennedy present in the very same book. Thanks to the authors' decision, we can find unique opinions and remarks concerning not only Adam Smith himself, but also his influence and our contemporary discussions.

It would be worth mentioning that the essays collected in this section also underline that the Scottish philosopher postulated not only the liberty of trade and individual decisions, but also some extent of regulation, as Maria Pia Paganelli has phrased it: "Smith believes regulation would make society both morally better and materially better off, as long as the regulation benefits the majority of the people, and not some at the expense of many. Indeed, the banking and monetary regulations that create concentrated benefits and disperse costs receive strong condemnation. The banking regulations that Smith calls for seem to be just a definition of the rules of the game that will allow competition to function at this best. And competitive forces allow for a fruitful moral and material development of the majority of the individuals" (Hanley, 2016, p. 259). Yet, the authors do not argue that Smith was a socialist - they simply notice that he had included in his economic views both space for individual economic freedom and for some extent of regulation that was to prevent the abuses and minimize negative effects of extensive greed and monopolies.

The essays that have been gathered in the fourth section of the book concern a wide variety of subjects: including Smith's moral theory, religion, history, jurisprudence, politics, and more. The greatest strength of this part of Adam Smith... is the fact that it introduces such a wide range of issues, presenting them in relation to some aspects of modern thought instead of solely mentioning the way they were presented by the author of the Theory of Moral Sentiments himself. Jacqueline Taylor even places Smith's thought in relation to feminist ethics, analyzing the role of resentment and sympathy the way they were understood by Smith. Lisa Herzog, when discussing modern ethics, underlines the aspect of human sociality in Smith's thought, underlining the discussion on the egalitarian aspects of his thought. She briefly describes the fact that morality of a person depends on that person's socialization, focusing on the influence of a community on an individual in acquiring cultural and moral patterns. Also connections between different aspects of 
Smith's thought were included in the discussed essays, e.g. Karen Valihora places together the role of imagination in moral judgement and the narrative structure of the Theory of Moral Sentiments. This part of the book can be found very interesting and inspiring both for the scholars who specialize in one aspect of Smith's thought and for those who have only started to become familiarized with his philosophy, as it presents numerous issues present in Smith's thought from a unique perspective.

The last, fifth, section of Adam Smith... presents the interpretations of Adam Smith's thought in today's categories. It deals with different aspects of Smith's philosophy analyzed in the framework of popular terminology: discussing his thought in comparison to the right-wing or left-wing, even reaching out to the reception of his ideas in China. The chapter written by Gavin Kennedy deals with some of the most common prejudices and stereotypes concerning Smith's thought: from laissez-faire, through "invisible hand" up to the understanding of self-interest. Kennedy points out that treating Smith as a person fully endorsing the idea of laissez-faire would be a mistake. Kennedy's discussion of the "invisible hand" focuses on the two usages of the term: the one in the Theory of Moral Sentiments and the other one in the Wealth of Nations - the only two in the works published while Smith was alive. The author only briefly mentions the fact that this phrase for the first time appeared in the History of Astronomy and does not present the discussion of the relation between the three usages of the notion. ${ }^{2}$ He focuses on its metaphorical use, noting that it was "[...]a popular metaphor used by over forty seventeenth- and eighteenth-century theologians and preachers, plus playwrights, novelists, and politicians” (Hanley, 2016, p. 465). However, Kennedy neglects to present the wide range of the ways of understanding the invisible hand. The author's remarks concerning the self-interest and selfishness are, sadly, too short. Such a widely discussed and nuanced issue deserves a more extensive analysis, especially in a book that shows such a wide variety of aspects of Smith's thought. Kennedy shows an interesting approach to the subject, focusing on the relation between persuasion and bargaining and self-interest. Nonetheless, his statement that "Persuasion and exchange eliminates Das Adam Smith Problem" (Hanley, 2016, p. 472) is an oversimplification, especially that the "Adam Smith Problem”

2 This issue has been discussed by various authors, including Macfie (1971), who stated that the Theory of Moral Sentiments and Wealth of Nations refer to the "invisible hand" to underline the idea of order, whereas the "invisible hand" present in the History of Astronomy describes rather the irregularities, Bishop (1995), who noticed that Smith tends to describe phenomena that can be classified as the results of the "invisible hand" without using the term itself, and Grampp (2000), according to whom Smith used the term in each of his works in a different meaning. 
itself, an issue present in academic discourse for over a century now ${ }^{3}$, was not fully described. The way of formulating the "Adam Smith Problem" has evolved through years and dealing with it on just a couple of pages seems like a very bold move, yet, the author's approach based on a deepened knowledge of the subject and an extensive bibliography are a good starting point for becoming accustomed with the issue and point out some common misunderstandings of Smith's thought.

Two essays in this section can be treated complimentary, as they discuss, respectively, "Adam Smith and the Left” (chapter by Samuel Fleischacker) and "Adam Smith and the Right” (by James R. Otteson). However, the way Samuel Fleischacker, whose great knowledge of the subject cannot be underestimated ${ }^{4}$, defines the "left" seems to be very selective. If we are to accept the fact that he lists " [...] five features generally mark movements associated with the left, in particular: [...] confidence that human beings can greatly improve their lot by the use of reason [...] trust the state over the private sector [...] strong egalitarianism [...] secular in orientation [...] true standard-bearer for human freedom” (Hanley, 2016, pp. 480-481), his analysis touches fascinating aspects of Smith's thought. Otteson, on the other hand, claims that such categories as "left" and "right" seem not to fit the analysis, as they are too vague and change through time. He postulates to "[...] therefore call the two positions centralist and decentralist, respectively" (Hanley, 2016, p. 495), which becomes the core of his interpretation that reaches out to both Theory of Moral Sentiments and Wealth of Nations. This chapter provides a very interesting analysis of Smith's thought, though it requires previous knowledge from the reader, as Otteson clearly frames his analysis in the terminology of his "market model”, presented in his two books on Adam Smith (Otteson, 2002; Otteson, 2013).

Adam Smith. His Life, Thought and Legacy proves to be a valuable contribution to the research on Adam Smith. Its strongest asset is the fact that it covers a wide range of issues and gathers the notable scholars working on the subject. The book mentioned issues rarely undertaken by the scholars in such collections, pointing attention to the less known aspects of Smith's philosophy. Such a number of essays devoted to various subjects results in the lack of a coherent strong idea standing behind the book. It might make it hard for a reader who is not familiar with the literature on Adam Smith to follow the discussion. Despite numerous issues discussed, the book fails to explore the relation between Smith's philosophy

3 One of the first texts discussing the "Adam Smith Problem” and showing that it's formulation has significant flows has been written back in the 19th century by August Oncken (1897).

4 Fleischacker's book (2004) is one of the very interesting analyses of the Wealth of Nations from the philosophical point of view. 
of science and his moral philosophy (despite the fact that Craig Smith's chapter on Essays on Philosophical Subjects is excellent). This collection of essays is a valuable addendum to the discussion on Adam Smith's philosophy, reaching out to modern frameworks of interpretation. Its unorthodox approach to some of the issues is a great contribution to the discussion. Adam Smith. His Life, Thought, and Legacy, cannot be treated as a textbook. It also proves that there is still a lot to be said about Adam Smith.

\section{References:}

Berry, Ch.J., Paganelli, M.P., Smith, C. (ed.) (2013), The Oxford Handbook of Adam Smith, Oxford: Oxford University Press.

Bishop, J.D. (1995). Adam Smith's Invisible Hand Argument. Journal of Business Ethics, 3 (14), pp. 165-180.

Fleischacker, S. (2004), On Adam Smith's Wealth of Nations, Princeton and Oxford: Princeton University Press.

Grampp, W.D. (2000). What did Smith Mean by the Invisible Hand. Journal of Political Economy, 3 (108), pp. 441-465.

Haakonssen, K. (ed.) (2006), The Cambridge Companion to Adam Smith, New York: Cambridge University Press.

Hanley, R.P. (ed.) (2016). Adam Smith. His Life, Thought and Legacy, Princeton and Oxford: Princeton Univeristy Press.

Macfie, A. (1971). The Invisible Hand of Jupiter. Journal of the History of Ideas, 4 (32), pp. 595-599.

Oncken, A. (1987). The Consistency of Adam Smith. The Economic Journal, 7 (27), pp. $443-450$.

Otteson, J.R. (2002). Adam Smith's Marketplace of Life, Cambridge: Cambridge University Press.

Otteson, J.R. (2013). Adam Smith, New York, London: Bloomsbury. 